\section{Vanja Erceg ${ }^{1}$}

Tihomir Zoranović ${ }^{2}$

University of Novi Sad, Faculty of Agriculture
ORIGINAL SCIENTIFIC ARTICLE doi: 10.5937/ekonomika2003047E

Received: March, 16. 2020.

Accepted: May, 04. 2020.

\title{
REQUIRED COMPETENCIES FOR SUCCESSFUL DIGITAL TRANSFORMATION
}

\begin{abstract}
In the middle of the Fourth Industrial Revolution there is a digital transformation that will completely change our understanding of business. The development of Industry 4.0 with technologies such as Cloud computing, the Internet of Things, and artificial intelligence will significantly impact on current business models. In order to successfully implement the digital transformation and survive in the global market, companies must own adequate intellectual capital. Apart from technical skills, employees will need to adapt to the new digital strategy, organizational structure, and business culture. In response to this trend, there is a need to establish new professions in companies. The aim of this paper is to try to find the answers to the next questions: which professions are needed to be introduced to companies that are digitally transformed and what is their role, as well as what competencies are necessary for company executives to successfully slow down digital transformation.
\end{abstract}

Key words: competences, digital transformation, $\mathrm{CIO}, \mathrm{CDO}$

JEL classification: 03, J24, M15

\section{КОМПЕТЕНЦИЈЕ ПОТРЕБНЕ ЗА УСПЕШНО СПРОВОЂЕЊЕ ДИГИТАЛНЕ ТРАНСФОРМАЦИЈЕ}

\begin{abstract}
Апстракт
У средишту Четврте индустријске револуције налази се дигитална трансформација која ће у потпуности променити наше разумевање пословања. Развој индустрије 4.0 са технологијама као што су CLOUD computing, Интернет ствари и вештачка интелигенщија значајно ће утицати на тренутне моделе пословања. Да би успешно спровеле дигиталну трансформаџију и опстале на глобалном тржишту, компаније морају да поседују адекватан интелектуални капитал, који се огледа у знању и вештинама запослених. Осим промене потребних техничких вештина запослени ће морати да се прилагоде новој дигиталној стратегији, организачионој структури, као и култури пословања. Као одговор на овај тренд појављује се потраба за успостављањем нових професија у компанијама. Циь овог рада је да пронађе одговоре на питана које професије је потребно увести у компаније које се дигитално трансформишу и
\end{abstract}

\footnotetext{
${ }^{1}$ vanja.erceg@gmail.com, ORCID ID 0000-0002-7451-6216

2 tihomir@polj.uns.ac.rs, ORCID ID 0000-0003-2564-5000
} 
која је њихова улога, као и које компетенщије је неопхоно да поседују руководиоци компанија како би се успешно споровела дигитална трансформација.

Кључне речи: иомпетенцес, дигитал трансформатион, СIO, СDO

\section{Introduction}

For several decades, technological progress has caused changes in business, social and economic relations. Technology trends such as social networks, Cloud computing, Big Data, artificial intelligence, the Internet of Things, and mobile technologies have a significant impact on processes, products, services and business models. Information technology is entering all areas of users' lives (Urbach, Drews, \& Ross, 2017). Specifically, technological innovations provide access to data that was not available so far (Nikolic, Vesic, and Cogoljevic, 2019), but also these and other opportunities that provide new digital technologies represent one of the biggest challenges companies face today ( Singh \& Hess, 2017). In the digital age, flexible and rapid adaptation of information systems is crucial. In the cases where the IT function cannot adapt to the new requirements, companies have to establish new business functions. With new business functions, there is a need for new professions. Also, knowledge management in the company becomes an imperative for successful business (Hebibi, Raimi and Milicićević, 2019). These changes in the labor market significantly affect the competencies that companies require from employees, as well as the way companies employ staff (Fitsilis, Tsoutsa, \& Gerogiannis, 2018). According to (Slvić, Bjekić, \& Berber, 2017) the importance of social networks such as e.g. LinkedIn and Facebook is growing in search of adequate staff. The structure of workers required for modern business is changing because modern technologies require trained and educated staff who are ready for continuous training (Stankić, Stojković, \& Soldić-Aleksić, 2018).

Even with a clear vision and an agile approach to realize and stimulate innovation, some companies still cannot cope with the challenges of digital transformation. Namely, unless the managers and employees have the adequate competencies required by digital transformation, it cannot be executed. Competence means a set of skills, knowledge and attitudes (Vey, Fandel-Meyer, Zipp, \& Schneider, 2017). Today coaching is mentioned as one of the most important values of profit-oriented companies. Specifically, coaching introduces a performance improvement technique that provides tools at the individual and organizational levels that help in the path to success (Szabó, Slavic, \& Berber, 2019).

The development of digital technologies is driving change that provides opportunities for more efficient business (Paunović and Veljović, 2018). Unlike the longestablished term information technology (IT), the term is digitally used to specify that something is different (Tumbas, Schmiedel, \& Vom Brocke, 2015). Specifically, more and more business departments are using digital technology to start innovation, in ways that go beyond the traditional capabilities of IT departments (Tumbas, Berente, \& vom Brocke, 2018). Until recently, the Chief Information Officer (CIO) was responsible for the digital use of innovation. However, for several years, companies have been expecting their CIOs to expand their roles from technology to business strategies, to achieve greater business value (Singh \& Hess, 2017). In regard to this background, businesses 
realize the need to introduce a new profession that will take responsibility for the jobs that the digital age imposes (Earley, 2017). In response to this demand, more and more companies are establishing an additional position at the highest level of management, and create a profession called Chief Digital Officer (CDO). The role of a CDO can be centralized or decentralized. Regardless of positioning, CDOs are there to make digital transformation a strategic priority in companies (Singh \& Hess, 2017).

\section{Methodology}

The standard methodology of systematic literature review recommended by (Brereton, Kitchenham, Budgen, Turner, \& Khalil, 2007), (Kitchenham et al., 2009) and (Kitchenham et al., 2010) was applied in the paper. The following are the required steps by the systematic literature review protocol.

\section{Defining research questions}

The research questions considered in the paper are:

RQ1: What professions appear with the digital transformation and what is their role? transformation?

RQ2: What competencies are required to successfully transmit digital

Analyzing the relevant literature selected on the basis of selected criteria, it can be seen that digital transformation has become a key topic in modern business flows (Erceg \& Zoranović, 2019). With the advent of this trend, it comes to the appearance of new professions that are necessary for modern business. RQ1 is set up to identify the new professions needed to manage digital transformation. Also, new jobs require the use of digital technologies, embracing the digital culture, changing the organizational structure and implementing a digital strategy, and sets up RQ2 to gain insight into the competencies needed to carry out digital transformation.

\section{Finding relevant research}

A search of the relevant literature for the topic was conducted manually at the Kobson Electronic Library (https://kobson.nb.rs/). The works were selected first by keywords, then by title, then by abstract and finally by conclusion. Keywords used for job search are: competences, digital transformation, CIO, CDO. The search for papers was conducted in English because of the relatively small number of data relevant to the topic in Serbian.

\section{Defining study inclusion and exclusion criteria}

The studies included in the study were published in the period 2015-2020. In addition to the time period, the criterion that the studies had to satisfy was that they were scientific papers published in a scientific journal or conference proceedings, doctoral dissertations and books. In the first search phase, 12,205 papers were found based on keywords. In the next step, based on the title were selected 2,035 papers which are considered to be relevant to the research topic. The following criterion referred to the 
selection of abstract-based works and 83 studies were selected. According to (Brereton et al., 2007), abstracts of information technology and software engineering papers are not sufficient to draw a conclusion if the study is relevant, so it is necessary to read the conclusions. According to this, after reading the conclusions there were selected 31 relevant studies. (Scheme 1).

Scheme 1. Phases of the process of selecting relevant studies

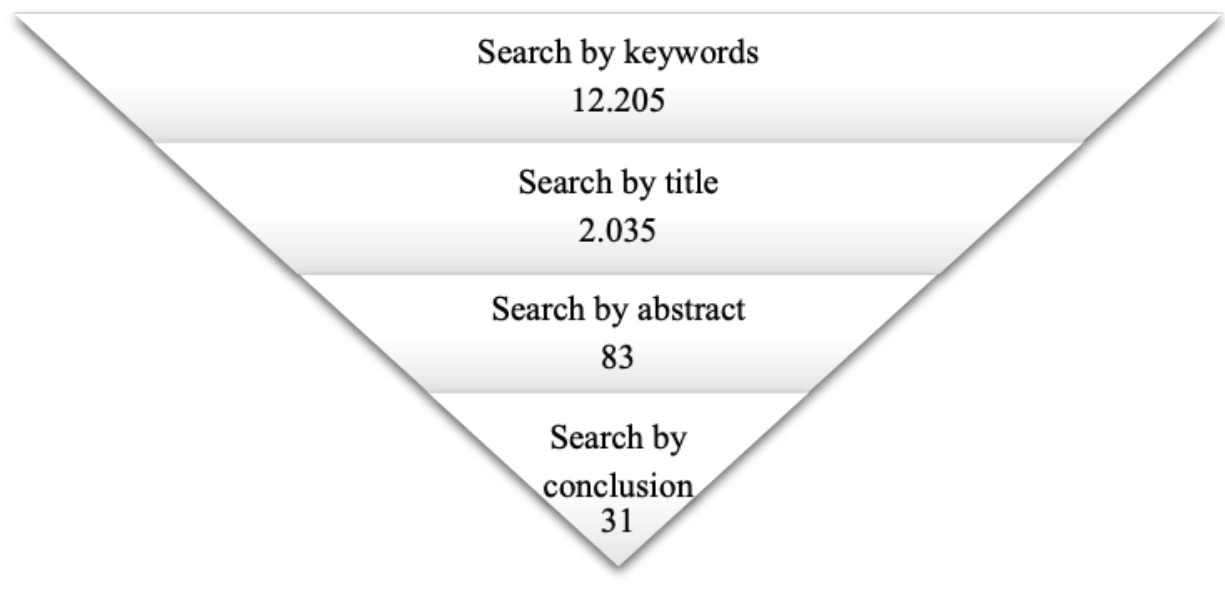

Source: Autor

\section{Qualitative assessment}

A systematic review of the literature was qualitatively assessed using criteria developed at the York University, Center for Reviews and Dissemination (CDR) Database of Abstracts of Reviews of Effects (DARE). The criteria are based on four questions:

1. Are the criteria for inclusions and exclusions studies dangerous?

2. Does the process of searching studies cover all relevant studies?

3 . Is the quality of the chosen studies assessed properly?

4. Are the basic data of study adequately presented?

In order to be included in the consideration, the studies had to meet all four criteria. The evaluation of the quality of the research material according to the defined criteria, as well as the extraction, analysis and synthesis of data from relevant studies, was performed using Mendeley software.

\section{Research results and Discussion}

Digital transformation is associated with a fundamental shift in peak performance and captures and include the external and internal dimensions of the enterprise (Erceg \& Zoranović, 2019). The success of digital business transformation is largely determined by the competencies of a digital strategy executor who nurtures a digital culture and which is able to change existing and establish a new business model. Risk-taking becomes a cultural norm as digitally mature companies seek new levels of competitive advantage (Kane, Palmer, Phillips, Kiron, \& Buckley, 2015). Equally 
important is that employees want to thrive and work for a business that is committed to digital advancement. According to (Aleksic-Glisovic, Jerotijevic, \& Jerotijevic, 2019) motivation for employees is a combination of meeting their needs and expectations about working conditions at a workplace. Company executives must take this into account to attract and retain the best staff. Therefore, digital transformation cannot be carried out without competent individuals who truly understand its meaning and complexity (Vey et al., 2017).

(Vey et al., 2017) In addition to their essential competencies, managers who believe in managing digital transformation should be professional and persistent in the face of employee resistance to digital transformation, continually support organizational change and actively help shape a culture that is reflected in ongoing learning, change and innovation. The ability to adapt quickly to change also stands out as an important feature. Perri Hevitt, chief digital officer at Harvard University, says that agility is more important than technology skills. It is agile processes that emphasize the importance of informal communication between actors, advocate small development teams instead of large structured units, and emphasize the value of any activity in the process of product or service development, while those activities that do not add value to the product are considered unnecessary (Erceg, Ciric, \& Zoranovic, 2019).

According to (Earley, 2017), a CDO influences business in the following ways: A CDO can increase the visibility of process issues and focus attention on innovation, unlike a CIO that does not have such breadth. The CDO focuses on cultural changes in the company. The CDO educates other executives about the importance of data. The $\mathrm{CDO}$ is focused on changing the process. The CDO focuses on the issue of data quality. It is important to emphasize that data quality management requires considerable effort because of the large number of stakeholders, processes, systems and applications that are affected. Data quality management is a key process for maintaining a competitive position in the market, because the quality of business decisions depends directly on the quality of the information. Poor data quality can lead to low data efficiency and consequently serious decision-making errors, which can later cause irreversible losses for the company (Erceg, Sheres, \& Zoranovic, 2019).

(Singh \& Hess, 2017) identified five competencies that CDOs should have. The first group of skills were called IT competencies. Specifically, new digital products and services are IT-based, so the CDO must understand IT applications and basic infrastructures, as well as how they can be upgraded and modified. The second group of competencies involves change management skills. The CDO needs to understand what new digital technologies mean for the business of the company and their customers. Not only do they need to understand what business models, business processes and customer needs are, but they also need to know the workings of various business functions, such as finance, marketing, sales, human resources and more. The third category of competence is inspirational skills. The CDO should be able to persuade all decision makers and employees that the need for digital transformation emerges and to highlight the benefits that will come from that transformation. In this regard, a CDO should have the ability to successfully overcome the resistance and barriers of employees which are often present in traditional corporate cultures. The fourth category of competence could be called digital pioneering skills. This means that the CDO must create a cohesive digital vision for the company. The CDO plays the role of a digital pioneer in the company, which requires a visionary mindset. The fifth 
feature that should excel at CDO is perseverance. Employees will not always accept the profound changes required for digital transformation, so the CDO needs to be persistent in its decisions in order for digital transformation to be successful.

According to (Fitsilis et al., 2018) the competencies required for digital transformation can be grouped into four categories. The first category refers to the technical competencies related to a specific job, such as process understanding and knowledge management. The second category is methodological competencies that include pre-emptive thinking, research skills, analytical skills, problem-solving ability and decision-making ability. The third group refers to social competencies, namely communication skills, teamwork, leadership skills and the ability to transfer knowledge. And the fourth category is personal competences, such as flexibility, motivation for continuous training and ability to work under pressure.

(Butschan, Heidenreich, Weber, \& Kraemer, 2019) consider that the role of human capital is crucial to drive innovation in companies. They divide competencies into the following categories: the first category is cognitive competencies, which they describe as the ability and motivation of employees to continuously learn and create new aspects in their work environment. Also, without technical knowledge combined with a general understanding of digital trends, it is not possible to use new tools and methods that are necessary for digital transformation. The next category is social competence. A large amount of information is collected in a very short time, so obtaining useful information in such situations, and even more so transferring that information, is a very difficult task. In addition, teamwork ability and flexibility are the defining traits. The next category is process competencies. Manufacturing processes are networked, flexible and agile, so it is required process understanding and a comprehensive approach. Employees, apart from performing their jobs, must actively follow parallel processes at both horizontal and vertical levels.

Table 1. Overview of competencies by author

\begin{tabular}{|c|c|c|c|c|c|c|}
\hline Year & Authors & \multicolumn{5}{|c|}{ Competency } \\
\hline 2017 & Vey et al. & perseverance & $\begin{array}{l}\text { introduction of } \\
\text { culture }\end{array}$ & agility & & \\
\hline 2017 & Earley & innovation & $\begin{array}{l}\text { introduction of } \\
\text { culture }\end{array}$ & $\begin{array}{l}\text { data } \\
\text { management }\end{array}$ & & \\
\hline 2017 & $\begin{array}{l}\text { Singh \& } \\
\text { Hess }\end{array}$ & tehnical & $\begin{array}{l}\text { change } \\
\text { management }\end{array}$ & innovation & $\begin{array}{l}\text { introduction } \\
\text { of culture }\end{array}$ & perseverance \\
\hline 2018 & $\begin{array}{l}\text { Fitsilis et } \\
\text { al. }\end{array}$ & tehnical & methodological & social & personal & \\
\hline 2019 & $\begin{array}{l}\text { Butschan } \\
\text { et al. }\end{array}$ & cognitive & social & process & & \\
\hline
\end{tabular}

Source: Autor

As new professions related to digital transformation are still evolving, this means that their role is different for different organizations (Tumbas et al., 2018). Most authors state that, in addition to technical skills, it is imperative that digital transformation executives possess the ability to agile adapt to change and perseverance in implementing transformation, especially when implementing digital culture into traditional structures (Table 1). Social skills and a methodical approach to process management are key to successful implementation of digital 
transformation. According to (Urbach \& Ahlemann, 2018) digital transformation in most companies required skills and competencies which are not immediately available. Although they can be developed within companies, they take a long time, which is not always available. This is why partnerships and networking are becoming increasingly important.

\section{Conclusion}

New technologies associated with digital transformation promise to improve business performance but require competencies that need to be improved. Classical IT tasks, such as working on IT infrastructure and application development, are increasingly overshadowed by the new demands of the digital age. New competencies such as IT service management, IT innovation prioritization, IT architecture management, change management as well as connecting customers, suppliers and partners are gaining in popularity. Traditional IT functions are not able to meet the demands of digital transformation, and it is necessary to introduce new professions. In addition to previous CIOs, digital transformation is introducing a new profession called $\mathrm{CDO}$, which has adequate competencies for its implementation and whose vision is strategically oriented.

\section{References}

Brereton, P., Kitchenham, B. A., Budgen, D., Turner, M., \& Khalil, M. (2007). Lessons from applying the systematic literature review process within the software engineering domain. Journal of Systems and Software, 80(4), 571-583. https:// doi.org/10.1016/j.jss.2006.07.009

Butschan, J., Heidenreich, S., Weber, B., \& Kraemer, T. (2019). Tackling hurdles to digital transformation - The role of competencies for successful IIoT implementation. International Journal of Innovation Management, 23(4), 0-5. https://doi.org/10.1142/S1363919619500361

Earley, S. (2017). The Evolving Role of the CDO. IT Professional, 19(1), 64-69. https://doi.org/10.1109/MITP.2017.4

Erceg, V., Ćirić, Z., \& Zoranović, T. (2019). Maturity in Agile Software Development Processes. Aplied Internet and Information Tehnology, IX, 353. https://doi. org/10.1111/j.1471-0528.1994.tb13676.x

Erceg, V., Šereš, L., \& Zoranović, T. (2019). Data Quality Assesment. Applied Internet and Information Tehnologies, IX, 353. https://doi.org/10.1111/j.1471-0528.1994.tb13676.x

Erceg, V., \& Zoranović, T. (2019). Digitalna transformacija poslovanja u poljoprivredi: Redizajn poslovnih rpocesa. Agroekonomika, 48(85).

Fitsilis, P., Tsoutsa, P., \& Gerogiannis, V. (2018). Industry 4.0: Required personnel competences. International Scientific Journal "Industry 4.0," 133(3), 4.

Kane, G. C., Palmer, D., Phillips, A. N., Kiron, D., \& Buckley, N. (2015). Strategy, Not Tehnology, drives Digital Transformation Becoming a Digitally Mature Enterprise. MIT Sloan Management Review. Retrieved from https://kityna.ga/146142.pdf 
Kitchenham, B., Pearl Brereton, O., Budgen, D., Turner, M., Bailey, J., \& Linkman, S. (2009). Systematic literature reviews in software engineering - A systematic literature review. Information and Software Technology, 51(1), 7-15. https://doi. org/10.1016/j.infsof.2008.09.009

Kitchenham, B., Pretorius, R., Budgen, D., Brereton, O. P., Turner, M., Niazi, M., \& Linkman, S. (2010). Systematic literature reviews in software engineering-A tertiary study. Information and Software Technology, 52(8), 792-805. https://doi. org/10.1016/j.infsof.2010.03.006

Paunović, L., \& Veljović, A. (2018). Modelling of the information system for monitoring the activities of a travel agency. Menadzment $u$ Hotelijerstvu $i$ Turizmu, 6(1), 31-39. https://doi.org/10.5937/menhottur1801031p

Singh, A., \& Hess, T. (2017). How Chief Digital Officers Promote the Digital Transformation of their Companies. MIS Quarterly Executive, 16(1), 31-44. Retrieved from http://cdoclub.com.

Slavić, A., Bjekić, R., \& Berber, N. (2017). The role of the internet and social networks in recruitment and selection process. Strategic Management, 22(3), 36-43.

Stankić, R., Stojković, D., \& Soldić-Aleksić, J. (2018). The analysis of the needs for business informatics specialists at the labor market of Serbia. Anali Ekonomskog Fakulteta u Subotici, 54(39), 235-247. https://doi.org/10.5937/aneksub1839235s

Szabó, S., Slavić, A., \& Berber, N. (2019). Coaching and its effects on individual and organizational performances in Central and Eastern Europe. Anali Ekonomskog Fakulteta u Subotici, 55(41), 67-80. https://doi.org/10.5937/aneksub1941067s

Tumbas, S., Berente, N., \& vom Brocke, J. (2018). Digital innovation and institutional entrepreneurship: Chief Digital Officer perspectives of their emerging role. Journal of Information Technology, 33(3), 188-202. https://doi.org/10.1057/ s41265-018-0055-0

Tumbas, S., Schmiedel, T., \& Vom Brocke, J. (2015). Characterizing multiple institutional logics for innovation with digital technologies. Proceedings of the Annual Hawaii International Conference on System Sciences, 2015-March, 4151-4160. https://doi.org/10.1109/HICSS.2015.498

Urbach, N., \& Ahlemann, F. (2018). IT Management in the Digital Age. https://doi. org/10.1177/1045159513499551.

Urbach, N., Drews, P., \& Ross, J. (2017). Digital Business Transformation and the Changing Role of the IT Function. MIS Quarterly Executive, 16(2), 2-4.

Vey, K., Fandel-Meyer, T., Zipp, J. S., \& Schneider, C. (2017). Learning \& Development in Times of Digital Transformation: Facilitating a Culture of Change and Innovation. International Journal of Advanced Corporate Learning (IJAC), 10(1), 22-32. Retrieved from https://online-journals.org/index.php/i-jac/ article/view/6334 